\title{
Legal and Ethical Aspects of Human Reproductive Cloning
}

\begin{abstract}
The aim of the essay is to explore the legal aspects of human reproductive cloning. Firstly, it gives a short introduction to the biological background of cloning, where special emphasis is laid upon the method of "somatic cell nuclear transfer" in connection with the existing forms of assisted reproductive technologies. The essay analyses the legal regulation in Hungary, Germany, England and the United States, and argues that the statutory prohibition of reproductive cloning often does not correspond to the biological facts, and this terminological ambiguity may lead to legal obscurity. Beyond that, the study also examines the factual and moral arguments against human reproductive cloning and the well-debated questions relating to reproductive rights, and finally, it attempts to search answers to what justifies the intervention and the rigid statutory ban on this field.
\end{abstract}

Keywords: human cloning, reproductive rights

\section{Introduction}

In the decades following World War II, Josef Mengele, who fled to South America, created viable embryos from the carefully preserved DNA of Adolf Hitler in the middle of the Brasilian jungle. According to a precise plan, the children born from these embryos were adopted by families all over the world.-The story comes from a movie of an Oscar winner director, called "The Boys from Brazil".

In general, human reproductive cloning is fully accompanied by a harsh rejection by societies and this negative hostility is affected by numberless science fiction movies and surreal conceptions about the reproduction of extremely famous and notorious persons or about the creation of a perfect army. ${ }^{1}$ However, the fact can be laid down: no man has been born by means of human reproductive cloning so far $^{2}$ and legislatures also call for a ban on this method of procreation.

It is certainly another point how we approach the topic of cloning. Would we think about-which may sound weird at first-that millions of "clones" are living in the world? They are called identical twins. ${ }^{3}$ Nevertheless, in this case the originally single embryo divides into two embryos under natural circumstances, in contrast to the scenario when it would be possible to create genetically identical progenies artificially.

* Ph.D., Senior Lecturer, Pázmány Péter Catholic University Faculty of Law and Political Sciences, H-1088 Budapest, Szentkirályi u. 28-30.

E-mail: navratyil.zoltan@jak.ppke.hu

1 Robertson, J. A.: Why Human Reproductive Cloning Should not in all Cases be Prohibited. Journal of Legislation and Public Policy, 4 (2000-2001) 1, 36; Harris, J.: On Cloning. London, 2004. 1; Sandor, J.: Introduction. In: Sandor, J. (ed.): Perfect Copy? Law and Ethics of Reproductive Medicine. Budapest, 2009. 8.

2 Elsner, D.: Just Another Reproductive Technology? The Ethics of Human Reproductive Cloning as an Experimental Medical Procedure. Journal of Medical Ethics, 32 (2006) 10, 596.

3 Silver, L. M.: Popular Cloning versus Scientific Cloning in Ethical Debates. Journal of Legislation and Public Policy, 4 (2000-2001) 1, 49. 
The following essay aims to explore the legal aspects of human reproductive cloning. Firstly, it gives a short introduction to the biological background of cloning, where special emphasis is laid upon the method of "somatic cell nuclear transfer" in connection with the existing forms of assisted reproductive technologies. The essay then analyses the legal regulation in the United States, Germany, England and Hungary. It argues that the statutory prohibition of reproductive cloning often does not correspond to the biological facts, and it draws the conclusion that the terminological vagueness may lead to legal obscurity. Beyond that, the essay also examines the moral arguments against human reproductive cloning and the well-debated questions relating to reproductive rights, and finally, it attempts to search answers to what justifies the intervention and the rigid statutory ban on this field.

\section{Background and hypothetical significance of reproductive cloning}

Cloning ${ }^{4}$ can be broken down into two categories: embryo splitting and somatic cell nuclear transfer.

(1) In the case of embryo splitting, the cells (the so-called blastomeres) of a 4-to 8-cell stage embryo in vitro are separated into pieces, this means that the method allows to create viable identical twin embryos artificially similarly to the naturally occurring twinning. In this stage of development the embryonic cells (the blastomeres) are "totipotent", which refers to that they are undifferentiated, possess the ability of self-renewal and they are capable to form any type of cell and can produce an entire organism, a whole human being. ${ }^{5}$

(2) The way of somatic cell nuclear transfer (SCNT) as compared to embryo splitting is more complicated, but it has demonstrated its biological success in the animal breeding, because this method led to the birth of the famous Scottish sheep named Dolly in $1997 .{ }^{6}$

In the course of SCNT the nucleus of an egg cell is removed and a nucleus of a somatic (body) cell, which contains the complete DNA, is transferred to the cytoplasm of the enucleated egg cell. The somatic cell can be any kind of body cells and it is gained from the individual that is to be cloned. Once the nucleus transfer has been done, the egg containing the genetic material of the nucleus of the somatic cell is artificially stimulated in order to begin to divide and to grow to form a viable embryo. ${ }^{7}$ Accordingly, the genetic blueprint of the cloned embryo is predicted by the genetic material of the nucleus of the somatic cell inserted into the enucleated egg.

However, it should be noted that the enucleated egg is not free from its original DNA because a small amount of so called mitochondrial DNA (mDNA) will be still remained in the egg-cytoplasm and thus mDNA will be inherited by the cloned embryo, though its

${ }^{4}$ Cloning itself is a kind of asexual reproduction. Several fields of science use the method of cloning, e.g. molecular biology or agriculture. See e.g. Shapiro, E. D. et al.: To Clone or not to Clone. Journal of Legislation and Public Policy, 4 (2000-2001) 1, 28.

5 Allegrucci, C.-Young, L. E.: Differences between Human Embryonic Stem Cell Lines. Human Reproduction Update, 13 (2007) 2, 103; Simson, S. E.: Breaking Barriers, Pushing Promise: America's Need for an Embryonic Stem Cell Regulatory Scheme. Brooklyn Journal of International Law, 34 (2009) 2, 538; Schütze, H.: Embryonale Humanstammzellen. Berlin, 2007. 5.

${ }^{6}$ Knowles, L. P.: Science Policy and the Law: Reproductive and Therapeutic Cloning. Journal of Legislation and Public Policy, 4 (2000-2001) 1, 14.

7 Cibelli, J. B. et al.: Somatic Cell Nuclear Transfer in Humans: Pronuclear and Early Embryonic Development. The Journal of Regenerative Medicine, 2 (2001) 5, 25. 
amount in the cytoplasm is less than $1 \%{ }^{8}$ So the cloned embryo as opposed to the way of embryo splitting will not be genetically totally identical to the donor of the nucleus of the somatic cell. ${ }^{9}$

The significance of SCNT resides in the groundbreaking promise of embryonic stem cell research and therapeutic cloning, which theme is beyond the scope of this essay. In that case the stem cells of a cloned early stage embryo with nearly perfect genetic matching may be used to treat numerous serious disorders. ${ }^{10}$ The aim of reproductive cloning would be to create another born and living human being, which is merely a hypothesis at present, but we could let our mind run upon it.

Albeit several social theories promulgate the superiority of sexual reproduction, which forms the basis of biological genetic diversity and variability, some authors suggest that reproductive cloning may complement the currently applied assisted reproductive technologies or it may offer an alternative to infertile couples.

Apart from popular science fiction, in some types of infertility the couple is unable to provide gametes for the creation of an in vitro embryo and donor gamete(s) is necessary to produce an offspring, but the child will have obviously no biological connection to either one or both would-be parents. In contrast to the previous case, reproductive cloning may provide an opportunity for the would-be parents to share a biological connection with the cloned offspring in particular circumstances.

For example in cases of male infertility a nucleus of a somatic cell collected from the man would be placed in the woman's enucleated egg and the resulting embryo would be implanted into the woman's uterus to carry the child to term. Both parents and no one else would have genetic connection with the child, the man through his nuclear DNA, the woman through her low mDNA remaining in the egg-cytoplasm. ${ }^{11}$

Reproductive cloning could also be applied to cases of female infertility, but in this situation, by all means, a donor enucleated egg would be required and one of the parents would not have genetic relationship to the child. ${ }^{12}$ Nevertheless, the advantage of this method would be that not the whole genetic material would be transmitted to the child by the egg donor, solely the low cytoplasmic mDNA.

In the first scenario, a stranger third-party donor would no more be needed for the assisted reproduction, while in the second one cloning would eliminate the transmission of the whole genetic trait of the egg donor. Consequently, traditional family structures could

${ }^{8}$ Camporesi, S.-Boniolo, J.: Fearing a Non-Existing Minotaur? The Ethical Challenges of Research on Cytoplasmic Hybrid Embryos. Journal of Medical Ethics, 34 (2008) 11, 822; Dinnyés, A.: Össejtek és a klónozás lehetőségei (Stem Cells and Possibilities of Cloning). Magyar Tudomány, XLX (2004) 4, 292.

9 Wolf, E.: Kerntransfer und Reprogrammierung-Anwendungen in der Biotechnologie und Tierzucht. In: Köhler, W. (Hrsg.): Klonen-Forschung und Ethik im Konflikt. Deutsche Akademie der Naturforscher Halle, 2000. 23; Kunich, J. C.: The Naked Clone. How Cloning Bans Threaten Our Personal Rights. Westport, 2003. 6.

${ }^{10}$ Hucho, F.: Probleme der Stamzellforschung. In: Bühl, A. (Hrsg.): Auf dem Weg zur biomächtigen Gesellschaft? Chancen und Risiken der Gentechnik. Wiesbaden, 2009. 255; Simson: op. cit. 539. Cibelli: op. cit. 25-30.

11 Robertson (2000-2001): op. cit. 37.

12 See ibid. 38 
be ensured by reproductive cloning under certain conditions. ${ }^{13}$ It should be mentioned that generally the main reason of reproduction whether natural or artificial is to have a genetically related child. ${ }^{14}$

Moreover, some authors emphasize that reproductive cloning could open the way for same-sex couples to have biologically related offspring, especially for lesbians without the need of a male donor, one party would provide an egg and the other a body cell. Certainly it would be more difficult for gay couples whereas reproduction would by all means require a donated egg (which would then be enucleated) but a gestational surrogate mother, too. ${ }^{15}$

\section{Vagueness of legal regulations}

Notwithstanding the legislatures nearly in each country agree that reproductive cloning should be banned, the legal regulation as compared to the intent of the law-makers lacks accuracy and precision. The statutes do not cover the biological possibilities.

The Hungarian Health Care Act sets forth the definition of embryo as the following: embryo means every living human embryo following the completion of fertilisation until the 12th week of gestation. ${ }^{16}$ However, in the biological sense, this definition does not concern an embryo created via SCNT, where the living human embryo comes into existence by cell fusion involving nuclear replacement and not by fertilisation involving sperm cells.

Beyond that, the Act also declares a prohibition on the artificially creation of "genetically identical" human beings. ${ }^{17}$ The terminology of this rule can be applied to the method of embryo splitting, but not to the process of SCNT. As it was presented previously, an embryo created via SCNT is not genetically totally identical to the ancestor because of the very low mDNA remaining in the cytoplasm of the enucleated egg.

The Oviedo Convention, which was promulgated in Hungary by an act in 2002, also poses a ban on interventions "seeking to create a human being genetically identical to another human being", however, the Convention faces with the biological facts as it states that the "term human being »genetically identical« to another human being means a human being sharing with another the same nuclear gene set". ${ }^{18}$

Similarly to the broad language of the Health Care Act, the terminology of the Hungarian Criminal Code regarding this field is also inadequate for the description of the biological reality. For example, the Criminal Code states that any person who uses a human

13 Andrews, L. B.: Is There a Right to Clone? Constitutional Challenges to Bans on Human Cloning. Harvard Journal of Law and Technology, 11 (1998) 3, 647; Brown, B.: Human Cloning and Genetic Engineering: The Case for Proceeding Cautiously. Albany Law Review, 65 (2002) 3, 666.

14 Strong, C.: Reproductive Cloning Combined with Genetic Modification. Journal of Medical Ethics, 31 (2005) 11, 655.

15 Robertson, J. A.: Gay and Lesbian Access to Assisted Reproductive Technology. Case Western Reserve Law Review, 55 (2004) 2, 366-367.

16 Act CLIV of 1997 on Health. Sec. 165. a).

17 Ibid. Sec. 185. (5).

18 Convention for the Protection of Human Rights and Dignity of the Human Being with regard to the Application of Biology and Medicine: Convention on Human Rights and Biomedicine (Oviedo, 4. IV. 1997). Additional Protocol to the Convention for the Protection of Human Rights and Dignity of the Human Being with regard to the Application of Biology and Medicine, on the Prohibition of Cloning Human Beings (Paris, 12. I. 1998). Articles 1.1 and 1.2. 
embryo to create several human embryos commits a felony offense, ${ }^{19}$ and any person who separates the cells of a human embryo, ${ }^{20}$ or any person who creates genetically equivalent human species commits a felony offense, too. ${ }^{21}$ These rules cover the method of embryo splitting, but neither of them could be applied to SCNT due to the aforesaid biological facts. Solely one criminal rule could be affected by SCNT, which prohibits the performance of medical experiments on human embryos or gametes without a licence, and prohibits the creation of human embryos for scientific purposes. ${ }^{22}$ The effect of this rule could be applied to whatever experiment or research and SCNT is still at experimental stage. Albeit, the meaning of embryo is also problematic under criminal law, because the Health Care Act is the base of the definition of the embryo which operates with the concept of fertilisation. As mentioned above, SCNT lacks fertilisation.

The problems with the terminology of the Hungarian law can be found in the German regulation too. The provisions concerning the meaning of an embryo of the German Embryo Protection Act lead also to a regulatory pitfall. According to the Act embryo means the human egg cell fertilised and capable of developing from time of fusion of the nuclei ${ }^{23}$ (i.e. the egg and the sperm). This definitive starting point does not cover the method of SCNT. The terminology of the ban of cloning is also inaccurate, it declares the prohibition of causing a human embryo to develop with the same genetic information as another human being.

In England the early legal definition of the embryo was similar to the Hungarian one, the Human Fertilisation and Embryology Act 1990 stated that embryo means a live human embryo where fertilisation is complete. ${ }^{24}$ It is apparent that the Act envisaged the merger of the gametes. Therefore, the Parliament adopted the Human Reproductive Cloning Act in 2001 which comprises the prohibition of placing in a woman an embryo created otherwise than by fertilisation. ${ }^{25}$ After the revision of the Human Fertilisation and Embryology Act in 2008, the Act already states that references to an embryo include an egg that is in the process of fertilisation or is undergoing any other process capable of resulting in an embryo. ${ }^{26}$ So, the regulation in England was amended due to the development of biotechnology.

In the United States President Bill Clinton was the first who wished to deal with the legislative responses of cloning. He issued an executive order in 1997 (in the year Dolly was born) banning the use of federal founds for human reproductive cloning research and urged the Congress to pass the proposed Human Cloning Prohibition Act. ${ }^{27}$ Notably, the Congress has not enacted any bills regarding human reproductive cloning yet. In spite of that there is no federal law on this subject, several states passed laws relating to prohibiting

19 Act IV of 1978 on the Criminal Code. Sec. 173/E (2) f).

20 Ibid. Sec. 173/F (2) b).

${ }^{21}$ Ibid. Sec. 173/G (1).

22 Ibid. Sec. 173/E (1).

23 Act for Protection of Embryos 1991. Sec. 8(1).

${ }^{24}$ Human Fertilisation and Embryology Act 1990. Sec. 1(1).

25 Human Reproductive Cloning Act 2001. Sec. 1(1). This Act was repealed in 2008 by the enactment of the new Human Fertilisation and Embryology Act.

${ }^{26}$ Human Fertilisation and Embryology Act 1990 (as amended). Sec. 1(2) (b).

27 Kunich: op. cit. 8. 
either expressly human reproductive cloning or the experiments carried out on human embryos. ${ }^{28}$ It should be mentioned that there are a large number of states which have no laws concerning reproductive cloning at all. ${ }^{29}$

\section{Factual concerns regarding human reproductive cloning}

The early overheated debates on the ethical and theoretical dimension of human reproductive cloning seem to be calmed down now, and evaluation occurs under more sober circumstances. It may play an important role in that after the creation of Dolly the vast majority of governments engaged themselves to adopt reassuring regulations prohibiting this type of human procreation, although the regulations are not complete.

Reproductive cloning would also be a kind of method to create an embryo, a child, a human being. However, it would be basically different from natural procreation and from current assisted reproductive technologies, because traditionally an embryo is a result of the fusion of an egg and a sperm, and the way of cloning would exclude the male gametes from the process. Furthermore, the genetic material of the cloned embryo would come almost entirely from one ancestor. ${ }^{30} \mathrm{Up}$ to this point there is no distinction between that and e.g. therapeutic cloning, the essential difference lies in the motive, the aim of reproductive cloning would be the birth of the cloned embryo.

If we read again Huxley's, Wells's or Merle's utopian novels, we can see that fiction did not absolutely come true, but it does not seem so extremely surreal. We do not have to forget that the several horrific prophecies about the cloning of masses largely ignore the scientific facts, but they demonstrate vigorously the social refusal of cloning, the fear from the unleashing Frankenstein's monster. ${ }^{31}$ However, it is nothing more than a mere fantasy. Due to the fact that therapeutic cloning, which aims to isolate embryonic stem cells from an early stage cloned embryo for therapeutic purposes has not been perfectly developed so far, ${ }^{32}$ maybe it cannot be expected that science could produce an entire viable and healthy human individual via reproductive cloning, even if procreative liberty would include the right to have a child through SCNT.

28 See Arkansas Code $\S 20-16-1002$; Louisiana Revised Statutes $\S 14: 87.2$; Maine Revised Statutes tit. 22 §1593; Michigan Complied Laws § 333.16274; Minnesota Statutes $\S 145.421,422$; North Dakota Century Code $\S 12.1-39$; South Dakota Codified Laws $\S 34-14-27$; Virginia Code $\S$ 32.1-162.32-2; Connecticut General Statutes § 19a-32d-19a-32g; Illinois Compiled Statutes $\S$ 410 110/; Iowa Code § 707C.1-707C.4; California Business and Professions Code $\S 16004,16105$ and California Health and Safety Code $\S 24185$, 24187; Maryland Code § 10-429-10-442; Massachusetts General Laws ch. 111L; New Jersey Statutes $§ 26: 2 Z-2$; Missouri Revised Statutes $\S$ 1.217 .

${ }^{29}$ Beyond that, the self-regulation of science involves some non-compulsory documents regarding this field. See e.g. the guidelines of the National Academy of Sciences or the guidelines of the Internetional Society for Stem Cell Research. Hynes, R. O. et al.: Guidelines for Human Embryonic Stem Cell Research. Washington, 2005. Daley, G. Q. et al.: Guidelines for the Conduct of Human Embryonic Stem Cell Research. Deerfield, 2006.

${ }^{30}$ Grad, F. P.: The Debate on Human Cloning and Legislative Morality: Notes on Eugenics for an Age of Affluence. Journal of Legislation and Public Policy, 4 (2000-2001) 1, 4. Shapiro: op. cit. 31 .

31 Kunich: op. cit. 2.

32 Doerflinger, R. M.: The Many Casualties of Cloning. The New Atlantis, Spring (2006) 62. 
Essentially, several arguments aim to challenge the idea of reproductive cloning, these could be organized into the following main categories.

(1) Religious and moral grounds: These claims rest on deep personal belief and focus on that an embryo is a human being with full moral status; that man should not intervene in the process of natural reproduction of humans; and that manipulations and experiments on human embryos should be rejected. ${ }^{33}$ The religious and moral grounds may frequently be of great relevance to the forthcoming reasons, too.

(2) Philosophical and ethical considerations are able to provide arguments about the thoughts of "good" and "evil", about the existential issues regarding "human condition" which could largely contribute to the support or condemnation of the idea of human reproductive cloning.

(3) The fundamental concept of the "slippery slope" argument regarding reproductive cloning has not a scientific but a science fictional origin. It warns that the allowing of human cloning for reproductive purposes could set off a chain reaction and may eventually lead to the creation of the perfect army or to the recreation of fallen tyrants of extinct eras etc. ${ }^{34}$

(4) The "playing God" argument is rooted in the religious and moral grounds, however, it can be seen separately as long as it is frequently noticed and has a solid characteristic. It means that man increasingly wants to transform and control what God (or Nature) has ordinated but without possessing God's wisdom. ${ }^{35}$

(5) Medical, physical grounds: these challenge the effectiveness and safety of the method of human reproductive cloning by SCNT and are of significant importance, because the technology of cloning is not either scientifically perfected in animal research.

(6) The legal concerns per se cannot be separated from the ethical, ideological and theoretical issues, which are necessarily taken into account by the legal evaluation and the development of a legislative pathway. ${ }^{36}$

It should be stressed that special emphasis can be laid upon medical grounds, these can be interpreted as the factual and rational arguments against human reproductive cloning.

Our current medical knowledge is grossly insufficient to allow a realistic expectation concerning a cloned human, it cannot be predicted whether a cloned human would suffer from birth defects or any other diseases later in life. ${ }^{37}$ Human reproductive cloning involves the use of a considerably complicated micromanipulation technique, e.g. the "genetic clock" of the transferred nucleus needs to be reset and reactivated, because it is not in the same level of development as the enucleated egg. Animal experiments provide wide range of reliable published data which demonstrate that the success rate of cloning by SCNT is low, the cloned animal frequently has an unstable genetic make-up, has hidden genetic abnormalities or has a short life expectation. The well-known example is Dolly the sheep, which was successfully born after 277 attempts and died six years after birth. ${ }^{38}$

33 Kunich: op. cit. 9-10.

34 Ibid. 12.

35 Kass, L. R.: Ageless Bodies, Happy Souls: Biotechnology and the Pursuit of Perfection. The New Atlantis, Spring (2003) 18.

36 Kunich: op. cit. 11-12.

37 Andrews: op. cit. 650.

38 Elsner: op. cit. 597. 
Furthermore, the genetic inheritance of future generations raises also tangible questions in relation to the method of SCNT. ${ }^{39}$ Notably, germ line manipulations and unexpected genetic mutations have an irreversible effect on all of the descendants of the affected human being. On the other hand, reproductive cloning would be an intervention into the genetic heritage of humanity as the genetic make-up of the cloned offspring would be transmitted from almost exclusively one person.

In sum, the medical and physical uncertainties of SCNT are deemed sufficiently serious to demolish the theory of human reproductive cloning. By virtue of these major concerns it is obviously premature to argue for the clinical application of SCNT whether or not it could be involved in the concept of reproductive freedom.

\section{Determining the "open future"}

Beyond the above broadly presented grounds there are further potential arguments which should be taken into consideration regarding the issue of reproductive cloning. Notwithstanding that the subject of human dignity, identity, instrumentalization and determinism may reach a philosophical dimension, it also generates a great deal of debates on the topic of cloning and could be of particular importance in the legislative framework, too.

It is a prevalent objection against reproductive cloning that a cloned individual would exist for particular purposes or determined expectations, and if the cloned individual fails to meet these wishful requirements, he or she would be deprived of all reason for existence to the creators. ${ }^{40}$ This conception could be fed by several phenomena, for example the parents might have a desire for replacing a deceased child by cloning or they might create a further offspring who could serve then as an organ or tissue bank for an existing but seriously ill child. Technique can be applied for many things. But we have to pay attention to the question: does any person have a right to an "open future"?

Accordingly, as some legal concerns suggest reproductive cloning for specific purposes would threaten the human dignity of the offspring and would have a devastating impact on our traditional conceptions about the beginning of life, there would be a glaring difference between an individual person with an independent open future and a copied person with a dependent determined future. ${ }^{41}$ Nevertheless, it should be explicitly stressed that reproductive cloning for specific purposes-and thus instrumentalization and objectivizationis not feasible in the constitutional and human rights framework of our societies. Consequently, every human being coming into existence by whatever means has the right to life and human dignity, because he or she is a born and living person. It could not be stated that the cloned person would have lower dignity and intrinsic value because he or she was conceived and born not by means of the union of an egg and sperm. This would be solely a biological fact which under no circumstances exhaust the concept of identity and personhood, ${ }^{42}$ and should not affect the legal perception of a born and living human being.

39 Brown: op. cit. 662.

40 Braun, K.: Menschenwürde und Biomedizin. Frankfurt am Main, 2000. 183.

${ }^{41}$ Gründel, J.: Läuft die Ethik immer "hinterher"? Zur Anwendung von Klon-Verfahren und genetischen Experimenten mit menschlischen Embryonen. In: Köhler, W. (Hrsg.): Klonen-Forschung und Ethik im Konflikt. Halle, 2000. 161.

42 Hottois, G.: Is Cloning the Absolute Evil? Human Reproduction Update, 4. (1998) 6,788. 
Hamlet's dilemma arises at this point: to be, or not to be. It would be nonsense to assert that a person is worse off if born through cloning than if never born at all. ${ }^{43}$ From a legal perspective it should be noted that an unconceived and unborn person possesses no such right like right to natural fertilisation or right to any genetic condition as an unconceived and unborn person also has not the right of not being born. The existence and the human nature of the cloned person could not be disavowed, and because of the biological, temporal and environmental influences the cloned person would not be identical to the ancestor neither physically nor psychologically. He or she would be a unique individual with unique identity and unpredictable future, and he or she would be entitled to all of the human and other rights. ${ }^{44}$

It should be emphasized that procreation through SCNT would also involve gestation, delivery and development, the method of human cloning could not produce an entire person itself with own personal identity. Neither the suddenness of nature nor the precision of science is able to create two totally identical human beings, the personality is impossible to be reproduced. ${ }^{45}$ This will be apparent if we draw our attention to the definition of genotype and phenotype of a person. Genotype means the genetic make-up, the inheritable genetic information of an individual, while phenotype refers to the observable characteristics and traits of an individual such as eye color or intelligence. However, even if some phenotypic traits are largely determined by genotype (e.g. eye color, height), there are a great number of characteristics which are the result of environmental factors or the interaction between genes and environment. ${ }^{46}$ Although genes have more or less influence on the person's physical and psychological features, the idea of genetic determinism-the one gene one trait-is widely obsolete. Moreover, naturally conceived identical twins exhibit same genotypes but different phenotypes. ${ }^{47}$

Notwithstanding that the principle of human dignity has played a key role during the preparation of human rights documents in the 20th century, and it can be seen as the ultimate source of human rights and a pervasive constitutional value, the definition of human dignity is perceived as an elusive, culturally embedded and nationally distinctive concept. ${ }^{48}$ We can accept the approach that the idea of dignity is metaphysically or philosophically complete and perfect, but in pragmatical and legal sense the theory of dignity is deficient and ambiguous, it needs additional interpretation. ${ }^{49}$ Thus, as international human rights documents and national laws frequently make reference to dignity per se in connection with outlawing human cloning-i.e. that human reproductive cloning violates human dignity-does not contribute to a reassuring result. For example it would be difficult to provide a solid interpretation to the provision of the Oviedo Convention which sets forth

43 Robertson (2000-2001): op. cit. 40.

44 Robertson (2000-2001): op. cit. 41. Grad: op. cit. 4.

45 Silver: op. cit. 52.

46 Brencsán, J.-Krúdy, E.: Orvosi szótár (Medical Dictionary). Budapest, 2002. 237, 507.

47 Kamm, F. M.: Cloning and Harm to Offspring. Journal of Legislation and Public Policy, 4 (2000-2001) 1, 66; Baum, K.: Golden Eggs: Towards the Rational Regulation of Oocyte Donation. Brigham Young University Law Review, (2001) 1, 120.

48 Carozza, P. G.: Human Dignity in Constitutional Adjudication. In: Ginsburg, T.-Dixon, R. (eds): Comparative Constitutional Law. Cheltenham, 2011. 460.

49 Ashcroft, R. E.: Making Sense of Dignity. Journal of Medical Ethics, 31 (2005) 11, 680; Kersten: op. cit. 473. 
that "the instrumentalisation of human beings through the deliberate creation of genetically identical human beings is contrary to human dignity". ${ }^{50}$

What is definitely common in all human beings irrespective of anything else? Which factors constitute the incontestable moral status of a human being? And, in particular, whose dignity would be violated by cloning?

Generally, the theory of human dignity could be apprehended in a European philosophical-cultural dimension, in which dignity is linked to the Kantian ethics. ${ }^{51}$ The Kantian principle states that a human being is an end in itself, does not have mere relative worth, but an intrinsic worth, a dignity. ${ }^{52}$ This ethos has had an overwhelming impact on the European human rights systems, however, the definition alone cannot be applied to biotechnology, it allows selective interpretation. Moreover, the blood, organ and tissue donation could be deemed prohibited under the shield of this doctrine.

Accordingly, it can be asserted that human reproductive cloning as a theoretical form of procreation would not attack the dignity of the cloned person, because it would serve the birth of the cloned person. ${ }^{53}$ The dignity of a person cannot be violated simply by coming into existence through any kind of method of procreation, otherwise the not-coming-intoexistence would be objectively the preferable situation.

It would be a more reasonable approach if we assumed that human reproductive cloning by SCNT could affect perhaps the dignity of the human race, and not the dignity of the individual person. In legal terms this could also signify that procreation via SCNT may raise comprehensive ethical and philosophical questions which highlight alternative ways for the legal regulation.

\section{The necessity of state intervention}

The theory of instrumentalization is also in tight connection with the aforesaid arguments, however, it has been appeared formerly in the area of the current forms of in vitro fertilisation, too. ${ }^{54}$ During the process of IVF more embryos are created in vitro than necessary for implantation and these surplus embryos are frequently discarded. Furthermore, often more embryos are implanted in order to increase the effectiveness of the method, but not every implanted embryo will lead to a successful pregnancy. A large number of embryos have solely a probability for a potential life, they are used as instruments to achieve one goal, the live birth of a healthy child.

50 Convention for the Protection of Human Rights and Dignity of the Human Being with regard to the Application of Biology and Medicine: Convention on Human Rights and Biomedicine (Oviedo, 4. IV. 1997). Additional Protocol to the Convention for the Protection of Human Rights and Dignity of the Human Being with regard to the Application of Biology and Medicine, on the Prohibition of Cloning Human Beings (Paris, 12. I. 1998). Preamble.

51 Harris, J.: "Goodbye Dolly". The Ethics of Human Cloning. Journal of Medical Ethics, 23 (1997) 6, 354.

52 "[...] der Mensch kann von keinem Menschen [...] bloß als Mittel, sondern muß jederzeit zugleich als Zweck gebraucht werden und darin besteht seine Würde.” Kant, I.: Die Metaphysik der Sitten. Zweiter Teil: Metaphysische Anfangsgründe der Tugendlehre. Königsberg, 1797, § 38.

53 Kersten: op. cit. 485.

54 Ibid. 484. 
The question is whether the theory of instrumentalization has a different or qualified meaning in relation to reproductive cloning. Cloning for particular purposes and for extreme ideas would exhaust the concept of instrumentalization. Accordingly, some commentators, especially in the United States argue that human reproductive cloning would be a form of "genetic slavery" labeling persons as properties and giving an overwhelming power to the creators; thus, reproductive cloning would be a new and radical form of instrumentalization and modern slavery. ${ }^{55}$ The assumptions behind this conception stem from the previously discussed arguments, but at this point it can also be stated that genetic determinism with particular expectations of the parents is totally without scientific value.

It should be noted that the idea of instrumentalization and its rebuttal is also theoretical. There is no vivid evidence that cloning as a type of human reproduction would be factually accompanied with intentional genetic manipulations for particular purposes. ${ }^{56}$ The "nonexistence paradox" presented above can be discovered in the instrumentalization argument, too: if the cloned person came into world, he or she would be subject to human rights as much as anybody else. The arguments against cloning give rise to speculations because we cannot certainly assert its opposite in the case of natural reproduction, where it would also be possible to conceive a child for particular purposes, the parents could have extreme expectations, the child could have unsuitable or irresponsible parents, the child's rights could be injured etc.

Nonetheless, it is widely accepted that the state does not interfere with the decision of the parents if they procreate naturally, but reproductive cloning is even theoretically far away from becoming a further method of assisted reproductive technologies.

In spite of this, the tendency is traceable. There is no manner of doubt that natural reproduction by sexual intercourse is an essential part of procreative liberty enjoying constitutional protection, it is a basic right of all persons to decide freely whether or not to have children. Biotechnology allowed to extend procreative rights to infertile couples or individuals, and several types of non-coital reproduction by means of assisted reproductive techniques have been granted legal recognition. At the same time, current assisted reproductive technologies involve human gametes, i.e. an egg and a sperm. In the case of reproductive cloning by SCNT conception occurs also artificially, but the fundamental difference is that the embryo is a result of the fusion of an egg and a nucleus of a somatic cell, the male gamete is excluded from the process.

Could human reproductive cloning by SCNT be inserted into the more and more extended frames of the right to procreate or the right to privacy in the future ${ }^{57}$

And what justifies the radical state intervention against researches aiming human reproductive cloning? What kind of higher values compel the state to prohibit the future exercise of the procreative freedom of this sort? Some proponents suggest that reproductive cloning as a form of becoming a parent is not qualitatively different from the other assisted reproductive techniques where genetic manipulation is also available. ${ }^{58}$ And in both cases the result is a child.

55 Andrews: op. cit. 668. The "slavery argument" is also highly emphasised by the Catholic Church. See e.g. Pontifical Academy of Life: Reflexions on Cloning. Vatican City, 2000.

56 Kersten: op. cit. 494.

57 Brown: op. cit. 668.

58 Andrews: op. cit. 665. 
It is difficult to find a tangible and logical explanation for the ban on carrying out researches on embryos with reproductive purposes. On the basis of the traditional democracy approach of Western cultures it could be outlined that legislatures for that very reason does not allow such a reproductive method because it is considered to be embarrassing and unpredictable and it is rejected by the vast majority of society. Simultaneously, other constitutional rights (like the right to procreate) are either not or only narrowly infringed by the prohibition. Probably, legislatures face with the medical and physical reasons, too. Additionally, it should not be forgotten that the method of cloning by SCNT without the male sperm would strongly affect our image about the beginning of human life, and the transcendency, mysticality and abstractum of human conception is hard to contest.

The condemnation of human reproductive cloning by societies originates in "offensive", "grotesque", "revolting", "repugnant" and "repulsive" feelings-and perhaps this could be portrayed as the "wisdom of repugnance". 59

59 Kass, L. R.: The Wisdom of Repugnance. In: Kass, L. R.-Wilson, J. Q. (eds): The Ethics of Human Cloning. Washington, 1998. 17. 